\title{
Assessment of Dithionite and Oxalate Extractable Iron and Aluminium Oxides on a Landscape on Basement Complex Soil in South-Western Nigeria
}

\author{
Olayinka Olakunle Olatunji, Yetunde Oyeyiola, Gbade Oyewunmi Oyediran \\ Crop Production and Soil Science Department, Ladoke Akintola University of Technology, Ogbomoso, Nigeria \\ Email: ola_marcus@yahoo.com,ooolatunji@lautech.edu.ng
}

Received 6 September 2015; accepted 20 November 2015; published 23 November 2015

Copyright (C) 2015 by authors and Scientific Research Publishing Inc.

This work is licensed under the Creative Commons Attribution International License (CC BY). http://creativecommons.org/licenses/by/4.0/

(c) $)$ (i) 0 pen Access

\section{Abstract}

The study investigats the morphological, physical and chemical characteristic of a toposequence on basement complex in Ejioku area, south-western Nigeria on latitude $07^{\circ} 28.675^{\prime} \mathrm{N}$; and longitude $004^{\circ} 07.219 ' \mathrm{E} ; 180 \mathrm{~m}$ above sea level at the upper slope. It terminates at the valley bottom on latitude $07^{\circ} 28.756^{\prime} \mathrm{N}$; and longitude $004^{\circ} 07.229^{\prime} \mathrm{E} ; 175 \mathrm{~m}$ above sea level. The topography of the site is moderately slope (not greater than $10 \%$ ). The aim is to examine the two forms of sesquioxides (crystalline-dithionite extractible $\mathrm{Fe} \& \mathrm{Al}$ and amorphous-oxalate $\mathrm{Fe} \& \mathrm{Al}$ ) and their distribution on the toposequence. The crystalline form of Fe oxide dominates all the positions and ranges from $7.2 \mathrm{~g} / \mathrm{kg}$ at the valley bottom to $444.3 \mathrm{~g} / \mathrm{kg}$ at the crest compared to the amorphous forms that range from $2.7 \mathrm{~g} / \mathrm{kg}$ to $10.9 \mathrm{~g} / \mathrm{kg}$. The crystalline and amorphous aluminium oxide contents of the soils are low $(2.9 \mathrm{~g} / \mathrm{kg}-43.3 \mathrm{~g} / \mathrm{kg}$ and $1.3 \mathrm{~g} / \mathrm{kg}-8.7 \mathrm{~g} / \mathrm{kg}$ respectively). There is significant negative relationship between $\mathrm{Fe}_{\mathrm{d}}$ and $\mathrm{Fe}_{\mathrm{d}} / \mathrm{Fe}_{\mathrm{o}}(r=-0.15 ; P<0.01 ; n=16)$. There is also a correlation between $\mathrm{Fe}_{\mathrm{o}}$ and $\mathrm{Al}_{\mathrm{d}}(r=0.63 ; P<0.01 ; n=16), \mathrm{Fe}_{0}$ and $\mathrm{Fe}_{0} / \mathrm{Fe}_{\mathrm{d}}(r=0.44 ; P<0.01 ; n=16)$, signifying a high level of weathering. The relatively high amount of $\mathrm{Fe}_{\mathrm{d}}$ virtually at all the horizons indicates that the crystalline and less active forms of the oxides exist more on the landscape and may be responsible for the non-availability of some nutrient like phosphorus that may be sorbed to their crystals lattice. All forms of $\mathrm{Al}$ in the soils are low especially, the oxalate extractable forms, when compare with the dithionite extractable forms. However, there is a significant correlation between $\mathrm{Al}_{\mathrm{d}}$ and $\mathrm{Fe}_{\mathrm{o}} / \mathrm{Fe}_{\mathrm{d}}(r=0.57 ; P<0.01)$. As a result of high accumulation of crystalline form of Fe and Al oxide with increasing depth, most especially, at the crest/upper slope, there is greater amount of concretions, nodules and plinthites which will lead to further deterioration of the soil for agricultural purposes. 


\section{Keywords}

\section{Plinthites, Sesquioxides, Toposequence, Dithionite Extractable, Oxalate Extractable}

\section{Introduction}

The features observable in a soil profile depend on the activity that goes on in it and how long they have taken place. It is however justifiable to say that characteristics of the soil as observed in a profile at a particular time depend on the interaction of factors and processes of soil formation. These factors have been enumerated as parent material, climate, organisms, relief and time [1]. Topography as a soil forming factor has dominant influence in determining differences among set of soils and their nutrient status. The set of soils are formed as a result of topography acting primarily as soil forming factors are called toposequence. Toposequence is also the succession of soils from a crest/plateau/summit to a valley bottom. The differences between soils of a toposequence are generally related to differences in their positions and drainage patterns, however, slope steepness is about the most important factor that causes variation in moisture condition along a toposequence [2]. According to [2], four groups of pedogenic processes result from slope effects are:

1) Powerful mechanical action (i.e. erosion);

2) Less powerful mechanical action i.e. lateral movement of clays (in suspension) and other materials in solution;

3) Transport in the form of pseudo and true solution;

4) Local changes in the moisture status and of the redox potential.

The different contribution of these will affect the type of variation observed at different location per time. In the basement complex area, there is a strong relationship between topographic position and soil genesis [2]. The differences in the rate of hydrologic and geomorphic process in various landform position causes differences in the types and intensity of pedogenic processes. This typically results in a non-random distribution of soil classes and properties on the landscape.

In tropical soils, free Fe oxides may be mobilized and deposited in soil profiles as Fe mottles, concretions, and hardpans [4]. Soils of the tropical region are dominantly alfisols, ultisols and oxisols and the dynamics of sesquioxides (iron and aluminum oxides) are progressively the determining factor for release of nutrient to planted crops [5].

Iron ( $\mathrm{Fe}$ ) and Aluminum (Al) found in soils are released during soil weathering and soil development; they are re-precipitated as amorphous or crystalline oxides, hydroxides or oxhydroxides [6]. Crystalline form is the predominant form of Fe in Alfisols which dominate the soils of Savanna region of Nigeria [5].

The crystalline form of Al-oxides is thought to be substituted into crystalline Fe-oxides such as geothites and heamatite [7]. The effect of such substitution is the structural distortion of crystalline Fe oxides with implications for anion retention and surface area [8] [9] studied the relationships between clay content and the acid oxalate extractable $\mathrm{Fe}$ and $\mathrm{Al}$ in some soils in Nigeria derived from sandstones and finds that the relationships are not significant. He, however, conclude that the amount and nature of the various forms of Fe and A1 oxides with organic complexes can greatly influence the physical and chemical properties of the soil. [10] conclude that the nature, amount and distribution of Iron ( $\mathrm{Fe}$ ) and Aluminum (Al) oxides in soil affect its ionic charge, chemical characteristics, and ion adsorption especially, phosphorus (P) sorption, surface charge and specific surface area. Swelling and aggregate formation may be significantly modified by the presence of amorphous $\mathrm{Fe}$ and $\mathrm{Al}$ oxides [11].

According to [12], the feature that distinguishes plinthites and accounts for hardness is greater degree of crystallinity and a continuity of the crystalline phase (i.e. the ratio of amorphous Iron $\left(\mathrm{Fe}_{\mathrm{o}}\right)$ to crystalline $\left(\mathrm{Fe}_{\mathrm{d}}\right)$, low $\mathrm{Fe}_{\mathrm{o}} / \mathrm{Fe}_{\mathrm{d}}$ ratio indicated high degree of crystallinity).

A large area of the rain forest and savannah zone of south western Nigeria is developed on basement complex, mostly Gneiss [13]-[15] in the classification of soils of south western Nigeria, evaluated some soil association with $\mathrm{Fe}$ and $\mathrm{Al}$ sesquioxides and pointed out the different soil series in where these oxides are predominant. This should be investigated to provide information on the forms, proportions and relationship among sesquioxides in these soils. 
More information is extremely needed for planning, uses and management of the soils. For these reasons Ejioku town, Lagelu Local Government area of Oyo State was selected haven't been an agrarian community producing most of the agricultural products of the state. Thus, this work was carried out to investigate the distribution and forms of sesquioxides on this landscape and determine the interrelationship between $\mathrm{Fe}$ and $\mathrm{Al}$ oxides with other soil properties.

\section{Materials and Methods}

\subsection{Description of the Study Site (Figure 1)}

The study area is Ejioku town; a derived savannah environment in south-western part of Nigeria. The location lies within latitude $07^{\circ} 28.675^{\prime} \mathrm{N}$ and $07^{\circ} 28.756^{\prime} \mathrm{N}$ with longitude $004^{\circ} 07.219^{\prime} \mathrm{E}$ and $004^{\circ} 07.229^{\prime} \mathrm{E}$. The elevation was $273.41 \mathrm{~m}$ above sea level at the crest and $178.31 \mathrm{~m}$ at the valley bottom. The toposequence was about 328 $\mathrm{m}$ long. The area is characterised with distinct dry (November to early March) and wet (April to October) seasons. Rainfall pattern is bimodal with peak periods in June and September, mean annual rainfall is about 1312 $\mathrm{mm}$. Temperature is about $27^{\circ} \mathrm{C}$, and reach its peak in February and March $\left(29^{\circ} \mathrm{C}\right.$ to $\left.32^{\circ} \mathrm{C}\right)$ respectively. The topography of the site is moderately slope $(<10 \%)$. The geology of the area is dominated by crystalline rock which forms part of the basement complex of south-western Nigeria and are generally of granitic parent materials.

Over the years, the soil had been put to different uses ranging from arable to permanent crops like maize, cassava, plantain and oil palm while some part had remained fallowed with tall grasses, trees and bush regrowth.

\subsection{Field Studies}

The whole area was mapped using the rigid grid method of soil survey in which transverses were cut and spaced at $50 \mathrm{~m}$ apart. Points of observation were fixed at the intersections of the perpendicularly running transects. After this, soils with similar characteristics were grouped together as same mapping unit. Soils on the landscape were delineated to upper slope, middle slope, lower slope and the valley bottom. Soil profile pits were located and dug $(1.5 \mathrm{~m} \times 1.5 \mathrm{~m} \times 2.0 \mathrm{~m})$ to represent each of the identified delineations on the field. Altogether a total of sixteen samples were collected from the four profile pits. Notes on morphological attributes in the soil profile were taken (soil colour, texture, structure, consistence, stoniness, mottles, Cutans and concretions).

\subsection{Analytical Procedures}

The samples collected were air dried and crushed to pass through $2 \mathrm{~mm}$ sieve. Prepared and labelled samples were taken to Soil Physics and Chemo-dynamics Laboratory, Soil Science Department, University of Manitoba,

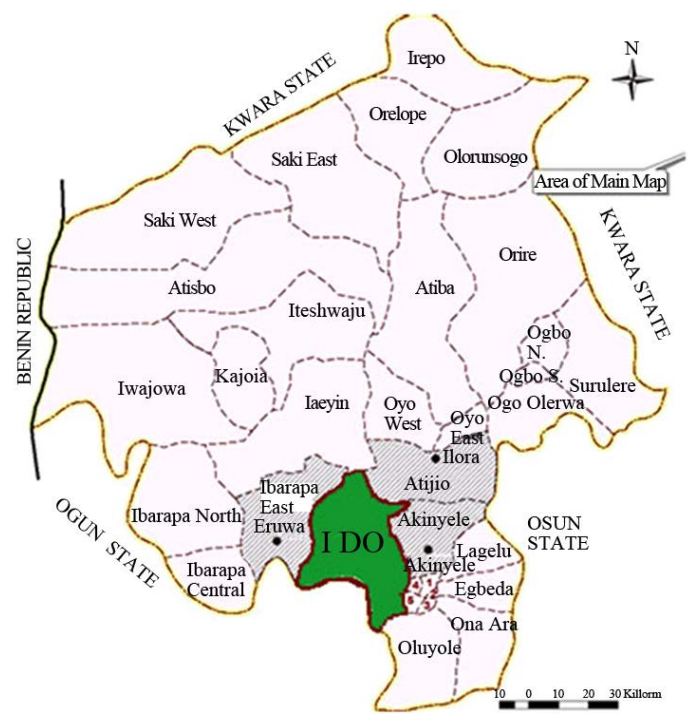

Figure 1. Map of Oyo State showing Lagelu Local Government area, area of the study site. 
Winnipeg, Canada for analysis. Extractable phosphorus was determined in Mehlich-III extractant by equilibrating $2.5 \mathrm{~g}$ of air dried soil sample with $25 \mathrm{ml}$ of Mehlich 3 extracting solution for $5 \mathrm{~min}$ and filtering through Whatman No. 40 filter paper [16] and the amount of phosphorus was determined using the colorimetric (ascorbic acid) method [17].

Ammonium oxalate extractable $\mathrm{Fe}, \mathrm{Al}$ and $\mathrm{Mn}$ were determined by shaking $0.5 \mathrm{~g}$ of soil with $20 \mathrm{ml}$ of ammonium oxalate extracting solution for 4 hours in the dark and then filtered using Whatman No. 40 filter paper [18]. Ammonium oxalate $\mathrm{Fe}, \mathrm{Al}$ and $\mathrm{Mn}$ in the extractant were determined by Inductive coupled plasma technique. The exchangeable cations and the cation exchange capacity (CEC) of the soil were determined using the ammonium acetate method [19]. Particle size distribution was determined using Hydrometer method [20], $\mathrm{pH}$ in ratio 1:2 (Soil: $\left.\mathrm{H}_{2} \mathrm{O}\right)$, Organic carbon was by [21].

Dithionite-Citrate Fe, Al and Mn were determined using the [22] soil conservation method. A $0.5 \mathrm{~g}$ of soil sample, ground to pass a 35-mesh sieve was weighed into a $50 \mathrm{ml}$ plastic centrifuge tube $(0.2 \mathrm{~g}$ for clays and $1 \mathrm{~g}$ for coarse soils). $25 \mathrm{ml}$ of the sodium citrate $\left(\mathrm{Na}_{3} \mathrm{C}_{6} \mathrm{H}_{5} \mathrm{O}_{7} \cdot 2 \mathrm{H}_{2} \mathrm{O}\right), 0.68 \mathrm{M}(200 \mathrm{~g} / \mathrm{L})$ solution was added. $0.4 \mathrm{~g}$ of dithionite (sodium hydrosulphite, $\mathrm{Na}_{2} \mathrm{~S}_{2} \mathrm{O}_{4}$ ) was also added. The centrifuge tube was covered tightly and put in an end-over-end shaker overnight and centrifuged for 20 minutes. The supernatant were filtered and determination of $\mathrm{Fe}, \mathrm{Al}$, and $\mathrm{Mn}$ was done by ICP-AES (inductive coupled plasma). This treatment is particularly useful for dissolving the "free" (non-silicate) $\mathrm{Fe}$ and $\mathrm{Al}$ in soils. The difference between the $\mathrm{Al}_{\mathrm{d}}$ and $\mathrm{Al}_{0}$ was assumed to be the $\mathrm{Al}^{3+}$ substituted for $\mathrm{Fe}^{3+}$ in the crystalline [23]. Determination of Total Nitrogen and Total Phosphorus was done by the Kjeldahl Method using a digestion mixture of $350 \mathrm{ml} \mathrm{H}_{2} \mathrm{O}_{2}, 0.42 \mathrm{~g}$ Se powder, $14 \mathrm{~g} \mathrm{Li}_{2} \mathrm{SO}_{4} \cdot \mathrm{H}_{2} \mathrm{O}$ and $420 \mathrm{~mL}$ conc. $\mathrm{H}_{2} \mathrm{SO}_{4}$ [24]. The concentration of $\mathrm{P}$ in solution was determined using the colorimetric method: Ascorbic method [25], while nitrogen was by titration method.

\subsection{Soil Classification}

The soils were classified according to soil taxonomy [22] and [26] soil legend while [15] soil classification was adopted at the series level.

\section{Result and Discussion}

\subsection{Soil Morphological Characteristics}

Generally 3 to 5 differentiated horizons were observed in all the profile pits, however; only 3 horizons were observable in the profile located at the valley bottom. This was due to the high water table encountered that prevented deeper examination. The important morphological characteristics of the soil are given in Table 1. Designation of the horizons are done according to the USDA soil taxonomy classification: AP represented the ploughed horizon, $\mathrm{AB}$ is the transitional point between the ploughed horizon and the $\mathrm{B}$ horizon. The $\mathrm{B}$ horizon is the subsoil with presence argillic features.

The landscape was delineated to upper slope, mid slope, lower slope and valley bottom. Pedon 1 was located at the upper slope and has a grayish yellow brown (10YR 5/2) topsoil coming down to bright yellowish brown (10YR 6/6) at the subsoil with five identified horizons.

Pedon 2 has a grayish brown (7.5YR 5/2). A horizon coming down to a (7.5YR 5/6) bright brown colour at the subsoil with four observable horizons.

Pedon 3 has grayish brown (7.5YR 4/2) topsoil that gradually changes to orange (7.5YR 6/8) at the subsoil while Pedon 4 was black (7.5YR 2/1) at the top and changes gradually to brown (7.5YR 4/4) at the subsoil.

At the valley bottom, the colour differs from the rest of the slope which was due to high water table content (7.5YR 2/1). The yellowish brown to orange colour observed at the upland subsoil is considered to be due to the mobilization and subsequent immobilization of iron during redox-cycles in the soil [3] [27] advanced this to be the causes of dispersion with progressive oxidation of iron. The bright subsoil colour in some of the profile may be an indication of good internal drainage, except the subsoil of pedon4 which was dull brown (7.5YR 4/4) as a result of high water table and poor internal drainage. Nearly all the soil profiles were mottled, however, mottleness was more prominent at the upland region, and this could be due to lack of mechanical mixing by plant roots and soil [28].

Surface soils were generally coarse sandy loam or sandy clay loam graduating into coarse fine sandy clay at the subsoil. The soil structure ranges from granular coarse at the surface of upland profiles to sub-angular blocky 


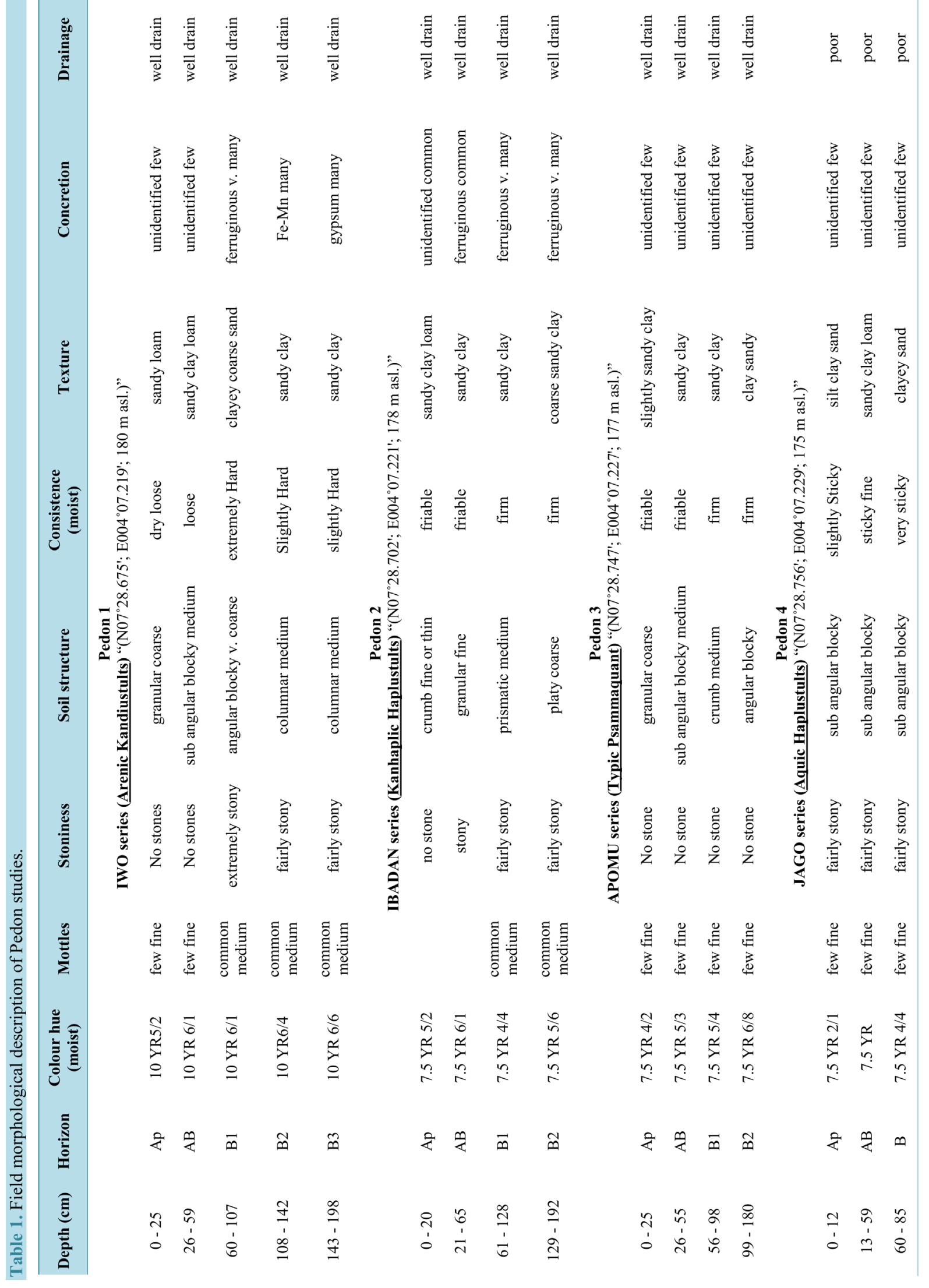


and fine at the valley bottom but the structure graduated to columnar, platy and sub angular blocky down the profile. This was due to the increase in clay content down the profile. Concretion was more of Fe-Mn component at the upper slope and ferruginous at the middle slope to unidentified and few at the lower slope. Sesquioxides concretion was iron noodles concretion; however, petro-plinthite and quartz materials are dominants in the horizons of Pedon 1 and 2. These are indicative of the granitic parent materials and alternate wetting and drying of the solum. According to [23], the presence of iron stone gravels in-situ in residual upland soils suggests that there had been possible segregation of iron in the form of plintholes. This process requires an adequate supply of iron, alternating wet and dry seasons a relatively flat land surface with seasonally wet soils [3] which could be found in the study area. This was also in line with the observations of [23] on some soils of Africa.

\subsection{Diagnostic Horizon and Intensity of Weathering}

Silt: Clay ratio is an indicator of weathering intensity and a ratio of $<0.15$ indicates low to moderate (Table 2) while a ratio of $>0.15$ indicates high intensity [2]. Thus all the Pedons showed evidence of high weathering intensity. The high silt content however reflects the probability of the soil being formed from coarse colluvial material (hill wash). This tends to suggest that erosion is an important pedogenic process in the study area (transportation).

\subsection{Physico-Chemical Properties of the Soils}

The AP horizon of all the pedons has high sand content (78\%) with low clay content. Generally, there was a decrease in sand with depth with clay accumulation at the subsoil. The silt/clay ratio is $>1$ at most horizons, however, in Pedon 4, silt/clay ratio was $<1$, suggesting a probability of ferallitic pedogenesis [29]. An outstanding feature of these soils across all the location on the topography is the moderate to high silt content $(6 \%-26 \%)$ down the profile. This increase in silt content can be due to the perturbation of soil aggregates during lessiviation and the washing down of the finer soil aggregate down the profile. This feature distinguishes the soils from most sandy soils at south-western Nigeria, which are characterized by low silt content $(<10 \%-15 \%)$ [2]. The high clay content in the deeper horizons of some of the soils (Pedon 1, 2 \& 3) with some morphological properties (Table 1 and Table 2) formed the basis for the recognition of argillic horizons in the region. Iron/Manganese (Fe/Mn) concretion ranges from many to common and occurred in most of the upland profiles (Table 1), suggesting the tendency of alternating wet and dry cycles, which could infer that plinthization may be a strong pedogenic processes in the study area. The high concentration of concretion may constitute a serious problem to crop production within the study area.

The soils on Pedon 1 was slightly acidic (5.7 - 6.7) to acidic and slightly acid in profile 2 (5.6 - 6.6), slightly acid in Pedon 3 (6.0 - 6.6) while Pedon 4 was strongly acidic (4.9 - 5.3). The factors that could be responsible for the strong acidic nature of Pedon 4 was the high water table condition of the valley bottom and poor drainage. The organic carbon content of the soil was generally low at the subsoil except on Pedon 2 and 3, where the organic carbon was higher at the subsoil. This is suggestive of a lithological discontinuity as a result of pedotransfer. Generally the organic carbon is considered to be low in all the soils which may be due partly to the impact of high temperature and high relative humidity, which favours rapid mineralization of organic matter components [30]. Also the different land use on landscape could be responsible for the lower organic carbon content at the topsoil when comparing the upland and with the valley bottom. However, the amount of organic carbon content cannot conveniently sustain a good crop production programme on a long term basis. Hence, a substantial improvement has to be made through effective crop residue incorporation management strategies.

The effective cation exchange capacity (ECEC) was low ranging from 2.1 to $15.8 \mathrm{Cmol} / \mathrm{kg}$. This could be in part due to the nature of parent material. The value indicate that the soils have low potential for retaining plant nutrients, and therefore call for an adequate soil management strategies such as, split fertilizer application and use of organo-mineral fertilizers.

In addition, these low values of ECEC in combination with low organic carbon and $\mathrm{pH}$ are indications of low, inherent soil fertility status, which emphasis the need for improved soil management techniques. This should be incorporated into the traditional methods of bush fallowing if good and long term crop production is to be sustained. Mehlich III extractable phosphorus (P) was generally low and considered inadequate for crop production, when compared with critical values recommended for most tropical crops (8 - 15 ppm) [31]. 


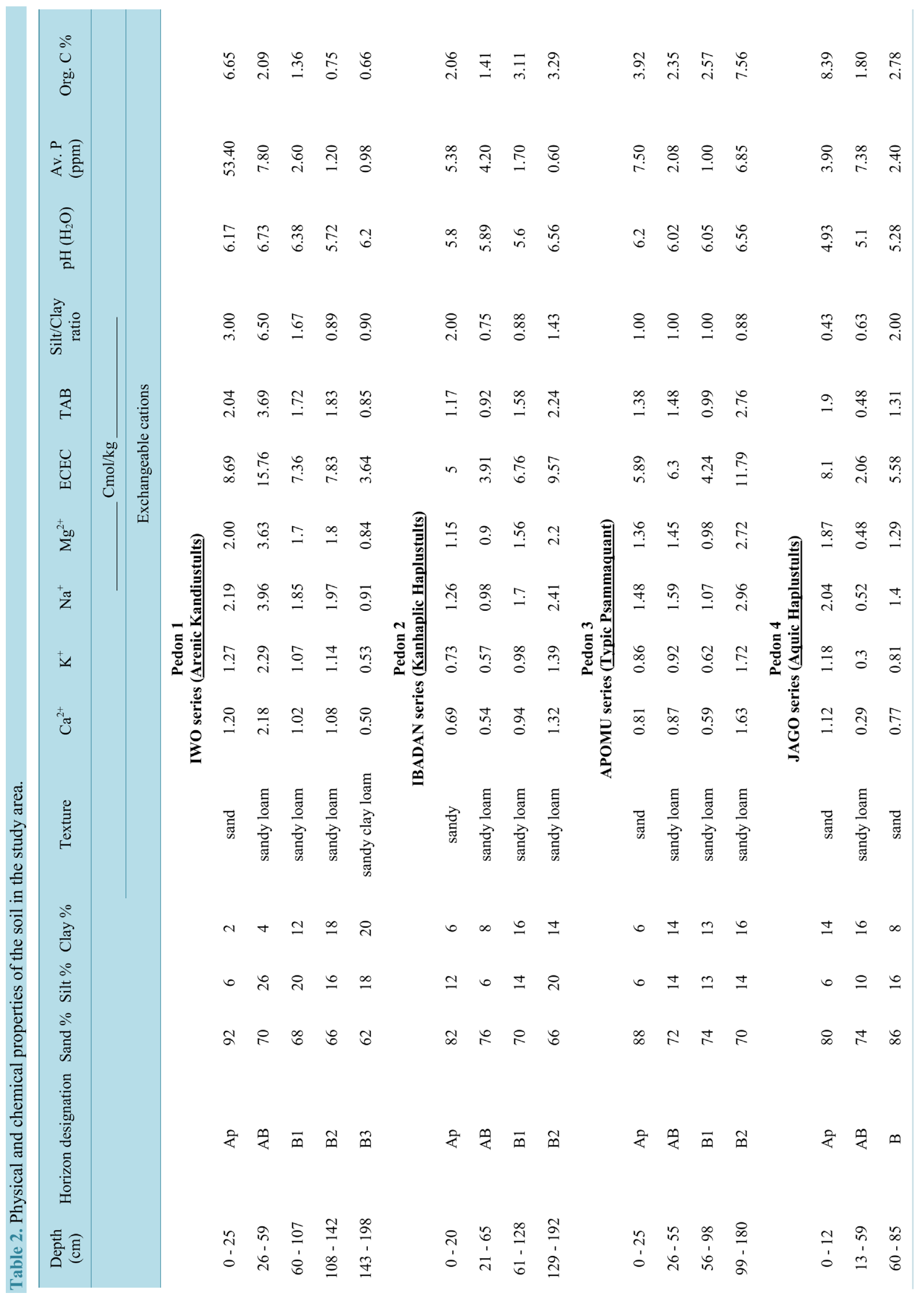




\subsection{Distribution of Dithionite and Oxalate Extractable Sesquioxides}

The data on the oxides of $\mathrm{Fe}$ and $\mathrm{Al}$ are shown in Table 3. The distribution of crystalline, non-crystalline and amorphous (poorly crystalline) forms of $\mathrm{Fe}, \mathrm{Al}$ and $\mathrm{Mn}$ oxides in the Pedons and their relationship are presented in Table 3. The citrate dithionate extractable only indicate the $\mathrm{Fe}$ and $\mathrm{Al}$ present in the soil are as free discrete bodies (i.e. crystalline and amorphous), and not as part of the structure of silicate minerals [28].

The free discrete bodies collectively referred to as un-combined or pedogenic free forms of the element [28] could either be mobile (amorphous) or immobile (crystalline). There was a wide margin in the distribution of dithionite and oxalate extractable $\mathrm{Fe}$ and $\mathrm{Al}$ within the horizons. The concentration of dithionite $\mathrm{Fe}$ and $\mathrm{Al}$ were greater than that of oxalate Fe and Al. However, there was a progressive increase in concentration of both dithionite and oxalate extractable Fe and Al down the profile in pedon 1 and Pedon 3, while Pedon 2 did not show any regular pattern in the distribution. Pedon 4 however showed a remarkable decrease in concentration down the profile.

All the Pedons had a lower $\mathrm{Fe}_{0}$ and $\mathrm{Al}_{0}$ at the $\mathrm{AB}$ horizon and the highest at $\mathrm{B}_{2}$. This phenomenon could be associated with topographic, parent material and land use effect on pedogenesis [28]. Among the pedons, $\mathrm{B}_{2}$ had the highest amount of $\mathrm{Fe}_{\mathrm{d}}$ except in Ibadan series where it was highest at $\mathrm{B}_{1}$. The ratio of free Fe to clay tends to vary regularly in all the Pedons and highest at the AP horizon and decreased down the profile.

Table 3. Distribution of various kinds of $\mathrm{Fe}$ and $\mathrm{Al}$ oxides in the pedons.

\begin{tabular}{|c|c|c|c|c|c|c|c|c|c|}
\hline Depth $(\mathrm{cm})$ & $\begin{array}{c}\text { Horizon } \\
\text { Designation }\end{array}$ & $\% \mathrm{Al}_{2} \mathrm{O}_{3(\mathrm{~d})}$ & $\% \mathrm{Fe}_{2} \mathrm{O}_{3(\mathrm{~d})}$ & $\% \mathrm{Mn}_{(\mathrm{d})}$ & $\% \mathrm{Al}_{2} \mathrm{O}_{3(\mathrm{o})}$ & $\% \mathrm{Fe}_{2} \mathrm{O}_{3(\mathrm{o})}$ & $\% \mathrm{Mn}_{(\mathrm{o})}$ & $\begin{array}{c}\mathrm{Fe}_{2} \mathrm{O}_{3(\mathrm{~d})} / \\
\text { Clay }\end{array}$ & $\begin{array}{c}\mathrm{Fe}_{2} \mathrm{O}_{3(\mathrm{O})} / \\
\mathrm{Fe}_{2} \mathrm{O}_{3(\mathrm{~d})}\end{array}$ \\
\hline
\end{tabular}

Pedon 1

IWO Series (를ic Kandiustults)

$\begin{array}{ccccccccccc}0-25 & \text { AP } & 6.66 & 38.15 & 1.33 & 3.04 & 7.34 & 1.78 & 19.08 & 0.19 & 0.46 \\ 26-59 & \text { AB } & 5.96 & 27.14 & 1.27 & 2.33 & 3.91 & 1.93 & 6.78 & 0.14 & 0.39 \\ 60-107 & \text { B1 } & 15.77 & 128.9 & 4.42 & 3.49 & 6.01 & 4.59 & 10.74 & 0.05 & 0.22 \\ 108-142 & \mathrm{~B}_{2} & 10.31 & 42.68 & 0.51 & 5.06 & 2.90 & 1.05 & 2.37 & 0.07 & 0.49 \\ 143-198 & \mathrm{~B}_{3} & 43.31 & 444.3 & 14.42 & 8.66 & 10.86 & 12.82 & 22.22 & 0.02 & 0.20 \\ & & & & & & & & & & \end{array}$

$\begin{array}{ccccccccccc}0-20 & \text { AP } & 22.14 & 222.75 & 3.84 & 6.10 & 6.75 & 4.13 & 37.13 & 0.03 & 0.28 \\ 21-65 & \text { AB } & 4.69 & 17.15 & 0.00 & 1.69 & 3.28 & 0.06 & 2.14 & 0.19 & 0.36 \\ 61-128 & \mathrm{~B}_{1} & 13.06 & 83.65 & 0.00 & 5.55 & 7.22 & 0.15 & 5.23 & 0.09 & 0.42 \\ 129-192 & \mathrm{~B}_{2} & 9.56 & 61.65 & 0.00 & 6.46 & 6.06 & 0.22 & 4.40 & 0.10 & 0.68\end{array}$

$\begin{array}{ccccccccccc}0-25 & \mathrm{AP} & 5.77 & 31.17 & 3.01 & 2.07 & 3.32 & 4.07 & 5.19 & 0.11 & 0.36 \\ 26-55 & \mathrm{AB} & 7.76 & 44.94 & 2.89 & 2.40 & 3.55 & 3.53 & 3.21 & 0.08 & 0.31 \\ 56-98 & \mathrm{~B}_{1} & 8.56 & 57.25 & 2.22 & 2.80 & 3.64 & 2.74 & 4.40 & 0.06 & 0.33 \\ 99-180 & \mathrm{~B}_{2} & 9.37 & 59.70 & 3.19 & 3.22 & 4.23 & 4.68 & 3.73 & 0.07 & 0.34\end{array}$

Pedon 4

JAGO Series (Aquic Haplustults)

\begin{tabular}{cccccccccccc}
$0-12$ & AP & 15.82 & 104.50 & 0.25 & 3.43 & 12.76 & 0.51 & 7.46 & 0.12 & 0.22 \\
$13-59$ & AB & 2.88 & 7.18 & 0.00 & 1.30 & 2.74 & 0.08 & 0.45 & 0.38 & 0.45 \\
$60-85$ & B & 3.57 & 22.74 & 0.00 & 1.95 & 7.54 & 0.20 & 2.84 & 0.33 & 0.55 \\
\hline
\end{tabular}

$\mathrm{d}=$ sodium citrate-bicarbonate-dithionite extractable; ${ }_{\mathrm{o}}=$ ammonium oxalate extractable; $\mathrm{Fe}=$ iron oxide; $\mathrm{Al}=$ aluminium oxide. 
The ratio of $\mathrm{Fe}_{\mathrm{o}} / \mathrm{Fe}_{\mathrm{d}}$ which serves as the index of the proportion of amorphous iron content and degree of crystalline of the soil was highest in the first two horizons at upper and lower slope. It increases down the profile at the valley bottom (Jago) except at the mid-slope where the ratio at the second horizon was almost double those of the other horizon in the Pedon.

Generally, there was significant negative relationship between $\mathrm{Fe}_{\mathrm{d}}$ and $\mathrm{Fe}_{\mathrm{d}} / \mathrm{Fe}_{\mathrm{o}}(r=-0.15 ; P<0.01)$. There are also correlation between $\mathrm{Fe}_{\mathrm{o}}$ and $\mathrm{Al}_{\mathrm{d}}(r=0.63 ; P<0.01)$ and $\mathrm{Fe}_{\mathrm{o}}$ and $\mathrm{Fe}_{\mathrm{o}} / \mathrm{Fe}_{\mathrm{d}}(r=0.44 ; P<0.01)$. The relatively high amount of $\mathrm{Fe}_{\mathrm{d}}$ virtually at all the horizons indicates that the crystalline and less active forms of the oxides exist more on the landscape and may be responsible for the non-availability of some nutrient like phosphorus that may be sorbed to their crystals lattice. Less emphasis is given to the distribution of various forms of $\mathrm{Al}$ in the soils as the quantities are much lowers especially the oxalate extractable forms. However, there are significant correlation between $\mathrm{Al}_{\mathrm{d}}$ and $\mathrm{Fe}_{\mathrm{o}}(r=0.63 ; P<0.01)$ and $\mathrm{Al}_{\mathrm{d}}$ and $\mathrm{Fe}_{\mathrm{o}} / \mathrm{Fe}_{\mathrm{d}}(r=0.57 ; P<0.01)$.

\section{Conclusion}

The results of this study have shown that the soils are relatively high in sesquioxides and their toxicity will definitely have an impact on the productive capacity of the soil. Crystalline forms as compared to the amorphous form dominate the free sesquioxides in the soils throughout the landscape. This shows that they have been highly weathered and the high proportion of crystalline form of $\mathrm{Fe}$ and $\mathrm{Al}$ will lead to structural distortion with implication for anion retention. The formation of hard pans and concretions can also lead to compaction of soil which can inhibit the penetration of plant root. Thus, very good and dynamic management technique and land uses are essential to ensure the preservation of the soil.

\section{Acknowledgements}

I acknowledged the contributions of The Canadian Bureau for International Education, through the Canadian Commonwealth Graduate Student's Exchange Program (GSEP) and Department of Soil Science, Faculty of Agricultural and Food Sciences, University of Manitoba, Canada.

\section{References}

[1] Juo, A.S.R., Moormann, F.R. and Maduakor, H.O. (1974) Forms and Pedogenetic Distribution of Extractable Iron and Aluminum of $\mathrm{P}, \mathrm{Fe}_{\mathrm{d}}$, and $\mathrm{Al}_{\mathrm{d}}$ in Selected Soils of Nigeria. Geoderma, 11, 167-179. http://dx.doi.org/10.1016/0016-7061(74)90015-9

[2] Ogunkunle, A.O. (1987) Influence of Micro Topography and Sampling on the Variability of Some Chemical Properties in Southern Nigeria. Tropical Agriculture (Trinidad), 64, 111-114.

[3] Fasina, A.S., Omolayo, F.O., Falodun, A.A. and Ajayi, O.S. (2007) Granitic Derived Soils in Humid Forest of SouthWestern Nigeria-Genesis Classification and Sustainable Management. American-Eurasian journal of Agiculture and Environmental Science, 2, 189-195.

[4] Ojanuga, A.G. (1978) Genesis of Soils in the Metamorphic Forest Region of South-Western Nigeria. Pedolomorphic Pedologie xxviii, 1, 105-117.

[5] Onweremadu, E.U., Omeke, J., Onyia, V.N., Aguand, C.M. and Onwubiko, N.C. (2007) Inter-Horizon Variability in Phosphorus-Sorption Capability of Sesquioxide-Rich Soils Southeastern Nigeria. Journal of American Science, 3, 4348.

[6] Guertal, W.R. (1994) The Pedologic Nature of Weathered Rock. In: Cremeens, D.L., et al., Eds., Whole Regolith Pedology, SSSA, Madison, 21-40.

[7] Ainsworth, C.C. and Sumner, M.E. (1985) Effect of Aluminum Substitution in Goethite on Phosphorus Adsorption. II. Rate of Adsorption. Soil Science Society of American Journal, 49, 1149-1153. http://dx.doi.org/10.2136/sssaj1985.03615995004900050015x

[8] Agbenin, J.O. (2003) Extractable Iron and Aluminum Effects on Phosphate Sorption in a Savanna Alfisol. Soil Science Society of American Journal, 67, 589-595. http://dx.doi.org/10.2136/sssaj2003.5890

[9] Udo, E.J. (1980) Profile Distribution of Iron Sesquioxides Contents in Selected Nigeria Soils. Journal of Agricultural Science, 95, 191-198. http://dx.doi.org/10.1017/S0021859600029439

[10] Torrent, J., Barron, V. and Schwertmann, U. (1990) Phosphate Adsorption and Desorption by Goethites Differing in Crystal Morphology. Soil Science Society of American Journal, 54, 1007-1012. http://dx.doi.org/10.2136/sssaj1990.03615995005400040012x 
[11] Angers, D.A. and Chenu, C. (1998) Dynamics of Soil Aggregation and Carbon Sequestration. In: Lal, R., Kimble, J.M., Follett, R.F. and Stewart, B.A., Eds., Soil Processes and the Carbon Cycle, Advances in Soil Science, CRC Press, 199206.

[12] Yaro, D.T. (2006) The Position of Plinthites in a Landscape and Its Effects on Soil Properties. PhD Thesis, Ahmadu Bello University, Zaria, 241.

[13] Okusami, T.A. and Oyediran, G.O. (1985) Slope-Soil Relationship on an Aberrant Toposequence in Ife Area of SouthWestern Nigeria: Variability in Soil Properties. Ife Journal of Agriculture, 7, 1-15.

[14] Amusan, A.A. and Ashaye, T.I. (1991) Granitic-Gneisis Derived Soils in Humid Forest Tropical South Western Nigeria I: Genesis and Classification. Ife Journal of Agriculture, 13, 1-10.

[15] Smyth, A.J. and Montgomery, R.F. (1962) Soil and Land Use in Central Western Nigeria. Govt. Press, Ibadan.

[16] Mehlich, A. (1984) Mehlich-III Soil Test Extractant: A Modification of Mehlich II Extractant. Communication in Soil Science and Plant Analysis, 15, 1409-1416. http://dx.doi.org/10.1080/00103628409367568

[17] Murphy, J. and Riley, J.P. (1962) A Modified Single Solution Method for the Determination of Phosphate in Natural Waters. Analytica Chimica Acta, 27, 31-36. http://dx.doi.org/10.1016/S0003-2670(00)88444-5

[18] Jackson, M.L., Lim, C.H. and Zelazny, L.W. (1986) Oxides, Hydroxides and Aluminosilicates. In: Klute, A., Ed., Methods of Soil Analysis, Part 1, Physical and Mineralogical Methods, 2nd Edition, Agronomy Monogram 9, ASA and SSSA, Madison, 101-150.

[19] McKeague, J.A. (1978) Manual on Soil Sampling and Methods of Analysis. 2nd Edition, Canadian Society of Soil Science, Ottawa, 212 p.

[20] Gee, G.W. and Or, D. (2002) Particle Size Analysis. In: Dane, J.H. and Topp, G.C., Eds., Methods of Soil Analysis, Part 4, Physical Methods, Soils Science Society of America, Book Series No. 5, Madison, 255-293.

[21] Nelson, D.W. and Sommers, L.E. (1982) Total Carbon, Organic Carbon and Organic Matter. In: Page, A.L., Miller, R.H. and Kenney, D.R., Eds., Methods of Soil Analysis, Part 2, American Society of Agronomy, Madison, 539-579.

[22] Soil Survey Staff (2006) Keys to Soil Taxonomy. 9th Edition, US Department of Agriculture, NRCS, Washington DC, 281.

[23] Fitzpatrick, R.W. and Schwertmann, U. (1982) Al-Substituted Goethite: An Indicator of Pedogenic and Other Weathering Environments in South Africa. Geoderma, 27, 335-347. http://dx.doi.org/10.1016/0016-7061(82)90022-2

[24] Akinremi, O.O., Armisen, N., Kashemand, A. and Janzen, H.H. (2003) Evaluation of Analytical Methods for Total P in Organic Amendments. Communications in Soil Science and Plant Analysis, 34, 2987-2997. http://dx.doi.org/10.1081/CSS-120025220

[25] Simard, R.R., Beauchemin, S. and Haygarth, P.M. (2000) Potential for Preferential Pathways of Phosphorus Transport. Journal of Environmental Quality, 29, 97-105. http://dx.doi.org/10.2134/jeq2000.00472425002900010012x

[26] FAO-ISRIC-ISSS (Food and Agriculture Organization of the United Nations, International Soil Reference and Information Centre, International Society for Soil Science) (2006) World Reference Base for Soil Resources. Report No. 103, FAO, Rome.

[27] Buol, S.W., Hole, F.D. and McCracken, R.J. (1980) Soil Genesis and Classification. Iowa State University Press, Ames, $404 \mathrm{p}$.

[28] Obi, J.C., Akinbola, G.E. and Anozie, H.I. (2009) Distribution of Dithionite and Oxalate Extractable Iron Oxides of a Catena in the Basement Complex of South-Western Nigeria. Nigeria Journal of Soil Science, 19, 100-119.

[29] Ashaye, T.I. (1969) Sesquioxide Status and Particle Size Distribution in Twelve Nigerian Soils Derived from Sandstones. African Soils Journal, 14, 85-96.

[30] Ibia, T.O. (2001) Forms of Fe and Al in Soil Particles of Inland Flood Plains of South-Eastern Nigeria. Proceeding of the 27th Annual Conference of the Soil Science Society of Nigeria, Calabar, 5-9 November 2001, 165-168.

[31] Obigbesan, G.O. (2001) Plant Mineral Nutrition in Nigeria: My Experience. In: Akorodon, M.O., Ed., Agronomy in Nigeria, Department of Agronomy, University of Ibadan, Ibadan, 188-194. 